\title{
ANALISIS FAKTOR-FAKTOR YANG MEMENGARUHI \\ KEMUNGKINAN TERJADINYA SALAH KELOLA ASET TETAP \\ DITINJAU DARI PERSPEKTIF FRAUD DIAMOND THEORY \\ (STUDI EMPIRIS PADA PERANGKAT DAERAH KABUPATEN SEMARANG)
}

\author{
Juni Ambarwati \\ Pemerintah Daerah Kabupaten Semarang \\ Rr Sri Handayani \\ Fakultas Ekonomika dan Bisnis, Universitas Diponegoro
}

\begin{abstract}
This study aims to analyze the factors that influence the occurance possibility of mismanagement of fixed assets by the state civil apparatus. This study based on the Fraud Diamond theory developed by Wolfe and Hermanson (2004). This study discusses mismanagement of fixed assets from the point of view of regional civil apparatus in the Semarang District Government. The population of this study is all regional civil apparatus in the Semarang District Government by census method. This research was conducted using primary data. Primary data in this study used a questionnaire (questionnaire) to measure the variables of financial pressure, habit pressure, work relationship pressure, pressure of other factors, perception of opportunity, general rationalization, authorization of functions, intelligence, ego and beliefs, coercion and fraud, ability to handle stress to fraud and mismanagement of fixed assets. The sample in this study amounted to 256 regional devices in the Semarang District Government. The data obtained were analyzed by using multiple linier regression. Based on the results of the analysis carried out, it was concluded that 6 variables: financial pressure, habit pressure, work relationship pressure, pressure of other factors, general rationalization, coercion and fraud to commit fraud had a positive effect to the occurance possibility of mismanagement of fixed assets. Then, the ability to handle stress when committing fraud has a negative effect to the occurance possibility of mismanagement of fixed assets, while other variables namely perception of opportunity, position authorization to commit fraud, intelligence to commit fraud and ego and confidence to commit fraud do not have influence to the mismanagement of fixed assets by regional equipment.
\end{abstract}

Keywords: Fraud Diamond Theory, Financial Pressure, Habit Pressure, Work Relationship Pressure, Pressure of Other Factors, Perception of Opportunity, General Rationalization, Position Authorization, Intelligence, Ego and Confidence, Coercion and Fraud also Ability to Cope with Stress, Mismanagement of Fixed Assets.

\section{PENDAHULUAN}

Salah kelola aset (asset misappropriation) sebagai salah satu bentuk fraud banyak terjadi pada berbagai negara di dunia, tindakan salah kelola aset tersebut mengakibatkan kerugian negara yang cukup besar. Pemilihan salah kelola aset tetap sebagai variabel dependen dalam penelitian ini karena salah kelola aset merupakan salah satu bentuk fraud paling umum dan paling banyak dilakukan oleh aparatur publik menurut laporan dari ACFE (2016). Fenomena salah kelola aset di dunia ditandai dengan adanya laporan 
The Association of Certified Fraud Examiners (ACFE), dimana salah kelola aset memberikan kontribusi sebesar $85 \%$ dari kasus fraud di seluruh dunia jika dibandingkan dengan tipe dan jenis fraud yang lain Nia dan Said (2015). Kasus fraud dalam bentuk salah kelola aset yang terjadi pada tahun 2015 mencapai 2.410 kasus fraud di tempat kerja yang terjadi pada 114 negara di seluruh dunia. Dan dari 959 kasus fraud di tempat kerja yang diteliti ACFE kerugian rata-rata mencapai \$ 175.000. (ACFE, 2016). Fenomena salah kelola aset di Indonesia dapat dilihat dari laporan IHPS BPK RI Semester I Tahun 2016. Menurut laporan tersebut komposisi kerugian negara berdasarkan permasalahan atas pemeriksaan LKKL Tahun 2015 menunjukkan bahwa salah kelola aset menempati peringkat tertinggi dibandingkan permasalahan lainnya. Fenomena salah kelola aset pada Pemerintah Daerah Kabupaten Semarang, dapat dilihat dari laporan hasil rekapitulasi temuan BPK Perwakilan Jawa Tengah yang diinventarisasi oleh Inspektorat Kabupaten Semarang dapat dilihat dari tren prosentase terjadinya salah kelola aset yang mengalami kenaikan dari tahun ke tahun selama 3 tahun terakhir.

Berdasarkan fenomena gap yang ditemukan di atas, pada penelitian ini akan meneliti lebih lanjut khususnya terhadap pegawai pada organisasi perangkat daerah
Pemerintah Daerah Kabupaten Semarang. Penelitian tentang salah kelola aset ditinjau dari perspektif fraud diamond theory dengan objek perangkat daerah pada OPD Pemerintah Daerah sejauh pengamatan penulis belum pernah dilakukan oleh penelitian sebelumnya, sehingga perlu diteliti lebih lanjut dengan pengembangan model dimensi yang membangun Fraud Diamond Theory.

Pembahasan teori Fraud Diamond tidak terlepas dari Fraud Triangle karena teori ini merupakan pengembangan dari Fraud Triangle atau segitiga kecurangan. Pengembangan kerangka teori Fraud Triangle dalam penelitian tentang faktor faktor penyebab fraud di kembangkan dalam kerangka teori Fraud Triangle, dimana konsep Fraud Triangle adalah sebuah gagasan penelitian tentang penyebab terjadinya tindakan kecurangan. Donald Cressey pada Tahun 1953 menciptakan sebuah gagasan yang dinamakan Fraud Triangle atau segitiga kecurangan. Adapun elemen dari segitiga kecurangan tersebut meliputi elemen tekanan, kesempatan, dan rasionalisasi.

Dalam beberapa periode teori segitiga kecurangan tersebut mengalami evolusi dan transformasi, yaitu pada tahun 1995 Albrecht mengganti elemen tekanan dengan motivasi, dengan anggapan semua jenis penipuan berasal dari motif seseorang. Karena terdapat anggapan 
tentang kelemahan pada teori segitiga penipuan tersebut maka beberapa penelitian melakukan kritik terhadap kelemahan Fraud Triangle Theory. Beberapa penelitian yang mengkritisi kelemahan Fraud Triangle Theory yaitu Mackevičius dan Giriūnas (2013), yaitu mengkritisi segitiga kecurangan yang hanya berfokus pada moralitas lemah perilaku individu saja dan mengesampingkan pada proses sosial budaya yang mempengaruhi perilaku individu tersebut. Menurut Marcevicious dan Giriunas elemen pertimbangan dimensi sosial dan ekonomi makro yang lebih luas adalah elemen yang sangat penting untuk memperoleh pemahaman tentang perilaku tidak etis yang akhirnya dapat menyebabkan tindakan penipuan. Pendekatan ini menyoroti nilai pandangan tentang penyebab penipuan tersebut terjadi dan memberikan wawasan tambahan pada asal usul sosial politik pelaku. Kritik lain dilakukan oleh Lokanan (2015), menurut hasil analisa Lokanan dari seluruh elemen tersebut baik dari tekanan, kesempatan, maupun rasionalisasi masih terdapat elemen utama yang memiliki peranan yang sangat penting dan berpengaruh yaitu adanya sistem pengendalian internal. Berdasarkan pengamatan Lokanan tersebut, penipuan terjadi karena adanya sistem pengendalian yang buruk.
Penelitian yang dilakukan oleh Wolfe and Hermanson (2004) menambahkan unsur baru pada elemen segitiga kecurangan yaitu unsur kemampuan/ kapabilitas disamping unsur tekanan, kesempatan dan rasionalisasi sehingga berubah menjadi persegi atau penipuan berlian dan dikenal sebagai Fraud Diamond Theory, karena Wolfe dan Hermanson beranggapan bahwa tanpa adanya unsur/ elemen kemampuan maka penipuan tidak akan terjadi.

$$
\text { Penelitian sebelumnya yang }
$$

meneliti telah faktor-faktor yang mempengaruhi fraud yang ditinjau dari perspektif Fraud Triangle Theory antara lain: Pamungkas (2015) meneliti tentang pengaruh antara tekanan, kesempatan serta rasionalisasi terhadap tindakan kecurangan akademik para siswa menyebutkan bahwa faktor tekanan, kesempatan dan rasionalisasi berpengaruh positif terhadap kemungkinan terjadinya kecurangan akademik para siswa. Penelitian yang sejenis juga dilakukan oleh Ekadah (2016)(Heider, 1958) yang hasilnya adalah faktor tekanan, kesempatan dan rasionalisasi bepengaruh positif terhadap penyalahgunaan aset. Demikian juga penelitian Wibowo (2017) menunjukkan bahwa seluruh elemen dalam fraud triangle berpengaruh positif dan signifikan terhadap asset misappropriation . 
Penelitian sebelumnya yang dikembangkan dalam kerangka teori Fraud Diamond dilakukan oleh Wolfe dan Hermanson (2004), menyebutkan 4 (empat) faktor yang menjadi penyebab terjadinya fraud yang terdiri dari : faktor tekanan atau pressure adalah sebuah dorongan atau suatu kebutuhan yang dialami seseorang untuk melakukan tindakan kecurangan atau fraud, kemudian faktor kedua yaitu peluang (opportunity) adalah situasi yang dapat membuka kemungkinkan suatu kecurangan terjadi, faktor ketiga yaitu rasionalisasi (rationalization) merupakan sikap menganggap benar pada tindakan kecurangan sehingga mereka merasionalisasi /membenarkan tindakan fraud.

Faktor keempat yang menjadi penyebab terjadinya fraud yaitu kemampuan (capability), menurut Wolfe dan Hermanson yang melakukan penelitian pada tahun 2004, seseorang yang akan melakukan tindakan kecurangan harus memiliki kemampuan untuk menyadari jalan atau cara yang terbuka sebagai sebuah peluang yang sangat menguntungkan untuk memanfaatkannya berkali-kali. Wolfe dan Hermanson (2004) berpendapat bahwa sebuah organisasi sangat perlu untuk mempertimbangkan kemampuan personal untuk melakukan tindakan fraud ketika mendesain suatu sistem deteksi. Menurut Wolfe dan Hermanson (2004) sangat penting untuk menambahkan elemen kemampuan, selain faktor tekanan, kesempatan dan rasionalisasi, karena penipuan tidak mungkin terjadi apabila seseorang tidak memiliki kemampuan untuk melakukannya.

Pengembangan kerangka teori Fraud Diamond ini telah dilakukan beberapa penelitian antara lain oleh Purnamasari and Okotroza (2015) yang meneliti pengaruh Fraud Diamond terhadap penyalahgunaan aset oleh karyawan BUMN, yang hasilnya menunjukkan kemampuan berpengaruh signifikan dan positif terhadap penyalahgunaan aset. Purwanto dkk (2016) menunjukkan bahwa seluruh elemen dalam fraud diamond berpengaruh positif dan signifikan terhadap fraud pengelolaan barang dan jasa. Irphani (2017) meneliti kemampuan yang diproksikan dengan jabatan pengelola keuangan yang hasilnya berpengaruh positif terhadap fraud di institusi pemerintahan.

Penelitian lain dalam kerangka Fraud Diamond Theory juga dilakukan oleh Ruankaew (2016) yang meneliti tentang faktor kapabilitas/ kemampuan terhadap penipuan diperoleh kesimpulan bahwa peluang membuka pintu untuk penipuan, insentif dan rasionalisasi sehingga dapat menarik seseorang ke arah 
penipuan, namun orang tersebut juga harus mempunyai kemampuan untuk mengetahui kesempatan dan untuk mengambil keuntungan dari hal itu. Menurut Ruankaew (2016) teori penipuan berlian atau Fraud Diamond Theory telah menyediakan kerangka kerja yang berharga, selain teori penipuan segitiga, yang dapat membantu para pemimpin bisnis dan praktisi untuk mencari solusi untuk meminimalkan atau mencegah perilaku kecurangan.

Berbeda dengan penelitian sebelumnya yang dilakukan antara lain oleh Purnamasari dan Okotroza (2015), Irphani (2017), Ekadah (2016), dan Purwanto dkk. (2016) sebagaimana telah diuraikan di atas yang dikembangkan dengan kerangka Fraud Diamond Theory, variabel tekanan, peluang, rasionalisasi dan kemampuan dalam penelitian ini akan dimanifestasikan dimana belum dilakukan pada penelitian sebelumnya. Penelitian ini mengadopsi serta melakukan penyesuaian berdasarkan hasil penelitian Albrecht, Kranacher dan Albrecht (2008) yaitu dengan mengukur pada konstruk-konstruk yang membangun variabel Fraud Diamond, yaitu untuk konstruk tekanan (pressure) akan dimanifestasikan dalam dimensi tekanan keuangan (financial pressure), tekanan karena kebiasaan (vice pressure), tekanan karena hubungan pekerjaan (work related pressure) dan tekanan karena faktor lain (other pressure), sedangkan konstruk peluang (opportunity) akan dimanifestasikan dalam dimensi persepsi kesempatan untuk melakukan kecurangan (perceived opportunity to commit fraud), konstruk rasionaliasasi (rationalization) akan dimanifestasikan dalam dimensi rasionalisasi umum untuk melakukan kecurangan (common rationalization to commit fraud), kemudian konstruk kemampuan (capability) dimanifestasikan dalam dimensi otorisasi posisi/ fungsi untuk melakukan kecurangan (position authorization to commit fraud), kecerdasan untuk melakukan kecurangan (intelligence to commit fraud), ego dan keyakinan untuk melakukan kecurangan (ego \& confidence to commit fraud), paksaan dan penipuan untuk melakukan kecurangan (coercion and deceit to commit fraud) serta kemampuan menangani stres dan resiko terdeteksi saat melakukan kecurangan (capability to handel stress to commit fraud).

Sesuai dengan teori Fraud Diamond pada penelitian menggunakan dimensidimensi yang lebih luas berdasarkan penelitian Albrecht, Kranacher dan Albrecht (2008) dengan melakukan beberapa modifikasi/ penyesuaian sesuai dengan karakteristik pegawai di Indonesia, 
serta untuk mengetahui lebih mendalam tentang pengukuran terhadap dimensidimensi terhadap salah kelola aset tetap serta melakukan perluasan penelitian untuk memberikan kontribusi terhadap pengembangan penelitian dengan teori Fraud Diamond. Faktor-faktor dalam fraud diamond tersebut akan diteliti melalui perspektif Fraud Diamond Theory dan kemudian akan dilakukan pengujian pengaruhnya terhadap kemungkinan tejadinya salah kelola aset tetap oleh pegawai sesuai dengan situasi dan keadaan yang ada di negara Indonesia.

Hasil penelitian ini dilakukan dengan harapan dapat memberikan tambahan manfaat kepada seluruh pihak yang membaca serta mendalami penelitian ini baik dari aspek teoritis, yaitu diharapkan dapat menambah literatur tentang teori Fraud Diamond dan salah kelola aset tetap. Selain itu, hasil penelitian ini diharapkan dapat dijadikan sebagai bahan referensi bagi peneliti selanjutnya. Sedangkan dari aspek praktis hasil dari temuan penelitian ini penulis berharap dapat menjadi saran serta masukan bagi organisasi publik umumnya dan khususnya bagi para stakeholder dan para regulator pada Pemerintah Daerah Kabupaten Semarang dalam mengambil kebijakan dan evaluasi internal control khususnya manajemen aset sehingga kemungkinan adanya salah kelola aset tetap bisa dihindari. Disamping itu juga sebagai sumbang saran untuk penguatan regulasi dalam meminimalisir tindakan fraud, juga untuk mengubah budaya organisasi yang mengakibatkan salah kelola aset tetap serta memberikan kontribusi praktis terhadap pencegahan tindakan salah kelola aset tetap.

\section{TINJAUAN PUSTAKA DAN PENGEMBANGAN HIPOTESIS Fraud Diamond Theory}

Pada penelitian ini dasar teori yang digunakan adalah Fraud Diamond Theory yaitu teori yang diperkenalkan oleh Wolfe dan Hermanson di CPA Jurnal pada bulan Desember tahun 2004 yang merupakan pengembangan dari Fraud Triangle Theory. Konsep Fraud Triangle atau segitiga kecurangan adalah sebuah gagasan yang meneliti tentang penyebab terjadinya tindakan kecurangan, gagasan ini pertama kali diciptakan oleh Donald Cressey pada Tahun 1953.

Tekanan merupakan sebuah dorongan atau kebutuhan seseorang untuk melakukan suatu tindakan kecurangan/ fraud. Tekanan (Pressure) mempunyai berbagai arti, antara lain keadaan seseorang saat merasa ditekan atau keadaan yang cukup berat ketika seseorang menghadapi kesulitan (Albrecht dkk., 2011). Albrecht mengklasifikasikan tekanan/pressure ke dalam 4 kelompok 
yaitu: financial pressure, vice pressure, work-related pressure dan other pressure. Elemen kedua dari Fraud Diamond berdasarkan penelitian yang dikemukakan oleh Cressey pada tahun 1950 adalah persepsi kesempatan. Kesempatan (opportunity) mencakup segala sesuatu yang membentuk keyakinan pelaku kecurangan untuk dapat melakukan kecurangan dan tidak akan tertangkap, kalaupun dia tertangkap tidak akan ada sesuatu yang serius menimpanya (Albrecht dkk., 2011).

Elemen ketiga adalah rasionalisasi, menurut Rae dan Subramanian (2008) rasionalisasi adalah pembenaran sikap dan perilaku penipuan hal ini terjadi karena kurangnya integritas pribadi pada pegawai, atau penalaran moral lainnya. Para pelaku tindakan kecurangan biasanya mencari pembenaran secara rasional agar orang lain membenarkan perbuatannya. Kemampuan ini adalah situasi yang memiliki ciri-ciri yang diperlukan atau keterampilan dan kemampuan bagi seseorang untuk melakukan penipuan. Posisi, kecerdasan, ego, pemaksaan, penipuan, dan stres adalah elemen pendukung kemampuan (Wolfe dan Hermanson, 2004).

Beberapa faktor kemampuan yang dimiliki oleh seseorang yang melakukan tindakan kecurangan atau penipuan, menurut Wolfe dan Hermanson (2004) yaitu: Otorisasi Posisi/ Fungsi atau Position Authorization dimana faktor awal yang memungkinkan penipu memiliki kemampuan untuk melakukan penipuan adalah fungsi atau memegang posisi tertentu dalam sebuah organisasi. Wolfe dan Hermanson2004) menyatakan bahwa posisi dan peran yang dimiliki oleh pegawai dapat menyempurnakan cara untuk melanggar kepercayaan organisasi. Kecerdasan/ kreativitas atau Intelligence, yaitu karakteristik berupa sikap, cerdas, berpengalaman, kreatif dengan pemahaman yang solid dari kontrol dan kerentanan, merupakan karakteristik dari pelaku penipuan terbesar saat ini. Pengetahuan ini digunakan untuk mempengaruhi perhatian individu untuk akses otorisasi untuk sistem atau aset. Penipu memiliki egoisme serta keyakinan yang kuat atau Ego and Confidenc bahwa ia tidak mungkin akan terdeteksi, atau percaya bahwa ia bisa dengan mudah mengambil jalan keluar dari kesulitan jika tertangkap.

Ego dan keyakinan bahwa perilaku penipuan tidak akan terdeteksi ini akan berdampak pada proses pengambilan keputusan mereka dengan demikian mereka lebih percaya diri dan semakin besar pula kesempatan mereka untuk melakukan penipuan. Paksaan dan penipuan atau Coercion and Deceit, 
karakteristik ini adalah seorang penipu harus mampu meyakinkan dan melakukan paksaan kepada orang lain untuk melakukan atau menyembunyikan penipuan, Kemampuan Menangani Stres atau Capability to Handle Stress yaitu kemampuan mereka untuk menangani stres karena seseorang yang melakukan penipuan membutuhkan jangka waktu yang panjang untuk mengelola stres dan resiko terdeteksi (Wolfe dan Hermanson, 2004).

Pemilihan salah kelola aset atau Asset Misappopriation dalam penelitian ini selain adanya fenomena salah kelola aset di tingkat dunia yang menimbulkan kerugian terbesar dari berbagai kategori fraud juga karena salah kelola aset merupakan bentuk fraud yang sering terjadi pada berbagai perusahaan karena skema salah kelola aset ini merupakan serangkaian aktivitas yang mencakup pencurian aset perusahaan seperti uang tunai, penyalahgunaan aset serta pencurian aset perusahaan.

Dalam penelitian ini dibatasi pada salah kelola aset tetap milik pemerintah daerah. Menurut Peraturan Menteri Dalam Negeri Nomor: 19 Tahun 2016, tentang Pedoman Pengelolaan Barang Daerah, yang dimaksud dengan Barang Milik Daerah adalah semua barang yang dibeli atau diperoleh atas beban APBD atau berasal dari perolehan lainnya yang sah.
Klasifikasi aset tetap menurut PSAP No.7 meliputi: tanah, peralatan dan mesin, gedung beserta bangunan, jalan irigasi dan jaringan, aset tetap lainnya serta konstruksi sedang dalam pengerjaan. Tahapan pengelolaan BMD terdiri dari: perencanan kebutuhan BMD, inventarisas BMD, penggunaan dan pemanfaatan BMD, pengawasan dan pengendalian BMD.

Penelitian sebelumnya dalam

kerangka Fraud Diamond Theory dilakukan oleh Apriadi (2014) menunjukkan bahwa tekanan yang diproksi dengan kesesuaian kompensasi, kesempatan yang diproksi dengan Sistem Pengendalian Internal (SPI) dan rasionalisasi yang diproksi dengan budaya etis organisasi mempunyai pengaruh yang positif terhadap tindakan fraud pada institusi pemerintahan/ Temuan Purnamasari dan Okotroza (2015) peluang yang diproksi dengan SPI berpengaruh positif dan signifikan terhadap fraud oleh karyawan. Irphani (2015) meneliti pengaruh tentang tekanan, kesempatan, rasionalisasi dan kesempatan mempunyai pengaruh yang positif dan signifikan terhadap fraud di sektor pemerintahan. Selain itu hasil penelitian Marliani dan Jogi (2015) juga menunjukkan bahwa tekanan, kesempatan serta rasionalisasi berpengaruh positif terhadap asset missapropriation. 
Penelitian yang sama dilakukan oleh Purwanto dkk. (2016) yang meneliti pengaruh elemen dalam Fraud Diamond terhadap fraud pengadaan barang dan jasa di sektor pemerintah, yang hasil temuannya adalah pressure, opportunity, rationalization dan capability berpengaruh positif dan signifikan terhadap fraud pengadaan barang dan jasa baik ketika diuji secara parsial maupun simultan.

\section{Gambar 1}

\section{Kerangka Pikir}

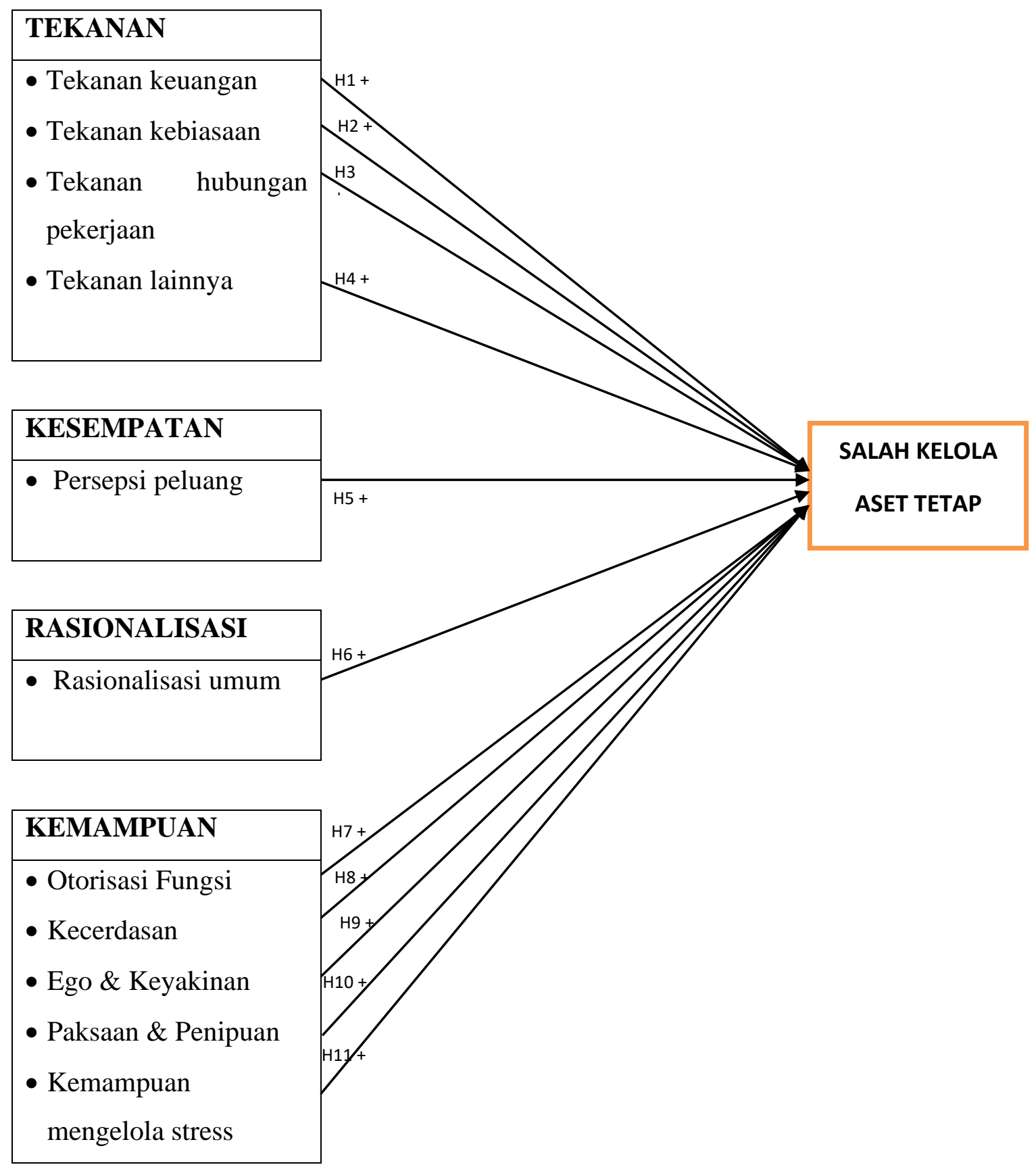




\section{Hipotesis Penelitian}

\section{Pengaruh Tekanan Keuangan}

(Financial Pressure) terhadap Salah

\section{Kelola Aset Tetap}

Menurut teori Fraud Diamond, tekanan keuangan (financial pressure) merupakan faktor tekanan yang berasal dari masalah keuangan seseorang diantaranya adalah: tekanan keuangan ini dapat mendorong seseorang untuk melakukan tindakan kecurangan, karena desakan kebutuhan keuangan yang harus segera diselesaikan. Penelitian Murdiansyah dan Nurkholis (2017) menunjukkan bahwa tekanan mempunyai pengaruh signifikan dan positif terhadap kecenderungan kecurangan akademik oleh mahasiswa dan Wibowo (2017) tekanan berpengaruh positif terhadap penyalahgunaan aset.

H1: Faktor tekanan kondisi keuangan (financial pressure) berpengaruh positif terhadap salah kelola aset tetap.

Pengaruh Tekanan Kebiasaan (Vice Pressure) terhadap Salah Kelola

\section{Aset Tetap}

Faktor tekanan non keuangan/ faktor kebiasaan antara lain: kebiasaan seseorang untuk berjudi (gambling), obat-obatan terlarang (drugs) dan seseorang yang memiliki kebiasaan sebagai peminum minuman beralkohol (alcoholic) serta hubungan diluar pernikahan (extra marital relationship) (Albrecht dkk., 2011). Faktor tekanan karena kebiasaan dapat memacu seseorang untuk melakukan kecurangan, seseorang dengan tekanan kebiasaan yang tinggi akan melakukan apa saja termasuk kecurangan untuk mendukung kebiasaan-kebiasaan tersebut, sehingga semakin tinggi tekanan kebiasaan seseorang maka semakin tinggi pula dorongan orang itu untuk melakukan tindakan kecurangan. Hasil penelitian Pamungkas (2015) tekanan akademik mempunyai pengaruh positif terhadap sikap/ tindakan kecurangan akademik pada siswa. Sedangkan menurut penelitian Irphani (2017) terdapat pengaruh yang signifikan positif antara variabel tekanan terhadap fraud di sektor pemerintahan.

H2: Faktor tekanan kebiasaan (vice pressure) berpengaruh positif terhadap salah kelola aset tetap 
Pengaruh Tekanan Hubungan

Pekerjaan (Work Related Pressure)

terhadap Salah Kelola Aset Tetap

Menurut Albrecht dkk. (2011)

tekanan hubungan pekerjaan juga mempengaruhi seseorang dalam melakukan tindakan fraud, hal ini biasanya berupa beberapa faktor yaitu: keinginan agar kinerja seseorang lebih mendapatkan pengakuan, seseorang merasa takut apabila suatu saat akan kehilangan pekerjaan atau seseorang memiliki keinginan untuk mendapatkan promosi jabatan. Menurut Ekadah (2016) dominasi tekanan dari faktor hubungan dengan lingkungan kerja bisa dipersepsikan dapat mendukung seseorang untuk melakukan tindakan kecurangan dalam hal ini berupa salah kelola aset, tekanan ini menggambarkan tekanan yang dialami seseorang sebagai bagian dari sebuah organisasi atau perusahaan. Penelitian sejenis juga dilakukan oleh Irphani (2017) yang meneliti pengaruh tekanan, kesempatan, rasionalisasi dan kemampuan terhadap tindakan fraud dalam institusi pemerintahan. Hasil penelitiannya diperoleh kesimpulan bahwa tekanan berpengaruh positif terhadap fraud di sektor pemerintahan. H3: Faktor tekanan hubungan pekerjaan (work related pressure) berpengaruh positif terhadap salah kelola aset tetap.

\section{Pengaruh Tekanan Lainnya (Other Pressure) terhadap Salah Kelola}

\section{Aset Tetap}

Menurut Albrecht dkk., 2011) tekanan dorongan lainnya juga merupakan salah satu penyebab seseorang melakukan tindakan fraud. Tekanan lainnya biasanya berupa pemikiran seseorang untuk membobol sistem yang sudah ada, selain itu adalah keinginan seseorang untuk menciptakan penampilan sukses, faktor lainnya adalah egoisme, kekuasaan dan kontrol, serta penyebab lainnya. Temuan Marliani dan Jogi (2015) menyebutkan bahwa tekanan yang berasal dari faktor lain dapat berasal dari diri pelaku misalnya keinginan untuk aktualisasi diri, maupaun keinginan untuk merusak/ membobol sistem yang sudah ada dapat mendorong seseorang melakukan asset misappropriation. Purnamasari dan Okotroza (2015) 
meneliti pengaruh tekanan, kesempatan, rasionalisasi dan kesempatan terhadap penyalahgunaan aset oleh karyawan BUMN. Hasilnya adalah faktor tekanan berpengaruh positif terhadap terjadinya tindakan penyalahgunaan aset oleh karyawan BUMN.

H4: Faktor tekanan lainnya (other pressure) berpengaruh positif terhadap salah kelola aset tetap.

$\begin{array}{lcr}\text { Pengaruh } & \text { Persepsi } & \text { Peluang/ } \\ \text { Kesempatan } & \text { untuk } & \text { melakukan }\end{array}$ kecurangan (Perceived Opportunities to commit fraud) terhadap Salah Kelola Aset Tetap

Menurut Cressey

kesempatan (opportunity) mencakup segala sesuatu yang membentuk keyakinan pelaku kecurangan untuk dapat melakukan kecurangan dan tidak akan tertangkap, kalaupun dia tertangkap tidak akan ada sesuatu yang serius menimpanya. Penelitian lain dilakukan oleh Pamungkas (2015) meneliti pengaruh tekanan, kesempatan dan rasionalisasi terhadap kecurangan akademik oleh para siswa. Hasilnya menyatakan bahwa peluang berpengaruh positif terhadap kecurangan akademik. Penelitian
Zahara (2017) mengungkapkan bahwa faktor kesempatan berpengaruh positif dan signifikan terhadap tindakan kecurangan (fraud) yang dilakukan oleh narapidana lembaga pemasyarakatan kelas IIa di Kota Pekanbaru dan penelitian Wibowo (2017) yang menunjukkan bahwa kesempatan berpengaruh positif terhadap penyalahgunaan aset.

H5: $\quad$ Faktor persepsi peluang (perceived opportunities) berpengaruh positif terhadap salah kelola aset tetap

\section{Pengaruh Rasionalisasi Umum untuk melakukan kecurangan} (Common Rationalisation to commit fraud) terhadap Salah Kelola Aset Tetap

Pelaku menganggap bahwa tindakan kecurangan/ penipuan hanyalah hal sepele atau hal kecil bahkan tidak penting untuk dibahas, sehingga tindakan salah kelola aset yang dilakukan tidak akan memberikan dampak yang besar dan menimbulkan kerugian, (Albrecht dkk., 2011). Penelitian Irphani (2017) menunjukkan bahwa rasionalisasi yang diukur dengan jabatan dalam pengelolaan keuangan berpengaruh positif terhadap terjadinya fraud. 
Menurut Devianasari (2016)

rasionalisasi yang diproksikan dengan

kultur organisasi berpengaruh

signifikan dan positif terhadap

terjadinya fraud pada sektor

pemerintahan. Penelitian lain

dilakukan oleh Wibowo (2017)

hasilnya menunjukkan bahwa

rasionalisasi berpengaruh positif

terhadap penyalahgunaan aset.

H6: Faktor rasionalisasi umum untuk melakukan kecurangan (common rationalization to commit fraud) berpengaruh positif terhadap salah kelola aset tetap.

\section{Pengaruh Otorisasi Posisi untuk} melakukan kecurangan (Position

Authorization to commit fraud) terhadap Salah Kelola Aset Tetap

Menurut Albrecht dkk. (2011) hanya orang yang mempunyai kapasitas yang sangat tinggi lebih dapat memahami pengendalian internal yang ada, untuk mengidentifikasi kelemahan dan menggunakannya dalam perencanaan pelaksanaan penipuan. Wolfe dan Hermanson (2004) menyebutkan bahwa kemampuan memungkinan seseorang untuk mengenali pintu atau cara yang terbuka sebagai kesempatan untuk mengambil keuntungan dari hal tersebut dan dilakukan secara berulang-ulang. Menurut hasil penelitian Ruankaew (2016) diperoleh hasil bahwa kemampuan menjadikan pintu masuk bagi seseorang dalam melakukan penipuan. Penelitian Purnamasari dan Okotroza (2015) hasilnya menunjukkan bahwa faktor kemampuan berpengaruh positif terhadap terjadinya penyalahgunaan aset oleh karyawan BUMN.

H7: Faktor otorisasi posisi untuk melakukan kecurangan (position authorization to commit fraud) berpengaruh positif terhadap salah kelola aset tetap.

Pengaruh Kecerdasan untuk melakukan kecurangan (Intelligence to commit fraud) terhadap Salah Kelola Aset Tetap

Kecerdasan dan kreativitas penipu adalah seseorang yang mengerti dan mampu memanfaatkan lemahnya sistem pengendalian internal serta menggunakan otorisasi posisi, fungsi maupun akses kewenangan untuk mengambil keuntungan yang lebih besar (Abdullahi dan Mansor, 
2015). Wolfe and Hermanson (2004) menyebutkan bahwa kemampuan memungkinan seseorang untuk mengenali pintu atau cara yang terbuka sebagai kesempatan untuk mengambil keuntungan dari itu dan berjalan berulangkali. Shelton (2014) meneliti pengaruh elemen kemampuan terhadap penyalahgunaan aset, hasilnya menunjukkan bahwa unsur kecerdasan pada elemen kapabilitas/ kemampuan yang dalam penelitian tersebut membandingkan antara kecerdasan dan keyakinan menunjukkan pengaruh yang signifikan terhadap kemampuan seseorang dalam penyalahgunaan aset.

H8: Faktor kecerdasan untuk melakukan kecurangan (intelligence to commit fraud) berpengaruh positif terhadap salah kelola aset tetap.

\section{Pengaruh Egoisme dan Keyakinan} untuk melakukan kecurangan (Ego and Confidence to commit fraud) terhadap Salah Kelola Aset Tetap

$$
\text { Menurut Wolfe dan }
$$

Hermanson (2004) sebagian penipu menemukan diri mereka sukses dalam kejahatan ini, mereka mulai mendapatkan beberapa hal yang menyenangkan dalam pengetahuan bahwa mereka bisa membodohi dunia, bahwa mereka menunjukkan superioritas mereka kepada orang lain. Penelitian sebelumnya dilakukan oleh Manurung dan Hardika (2015) yang meneliti tentang elemen tekanan, kesempatan, rasionalisasi dan elemen kemampuan terhadap kecurangan pelaporan keuangan. Hasilnya menunjukkan bahwa elemen kemampuan yang diproksi dengan perputaran direksi mempunyai pengaruh yang signifikan dan positif kepada tindakan kecurangan pelaporan keuangan.

H9: Faktor ego dan keyakinan untuk melakukan kecurangan (ego and confidence to commit fraud) berpengaruh positif terhadap salah kelola aset tetap.

Pengaruh Paksaan dan Penipuan untuk melakukan kecurangan atau (Coercion and Deceit to commit fraud) terhadap Salah Kelola Aset Tetap

Menurut Wolfe and Hermanson (2004) penipu sukses juga harus berbohong secara terus menerus. Dengan demikian penipu juga harus memiliki ketrampilan untuk melacak kebohongan sehingga cerita secara 
keseluruhan tetap konsisten. Menurut Shelton (2014) yang meneliti pengaruh elemen capability/ kemampuan terhadap penyalahgunaan aset, hasilnya menunjukkan bahwa unsur paksaan pada elemen kapabilitas/ kemampuan yang dalam penelitian tersebut membandingkan antara paksaan dan penipuan mempunyai pengaruh yang signifikan terhadap penyalahgunaan aset oleh karyawan. Menurut temuan Shelton (2014) seseorang dengan kondisi sikap dan kepribadian yang sangat persuasif mampu membuat orang lain yakin dan ikut serta melakukan penipuan.

H10: Faktor paksaan dan penipuan untuk melakukan kecurangan (coercion and deceit to commit fraud) berpengaruh positif terhadap salah kelola aset tetap.

Pengaruh Kemampuan Menangani Stres dan resiko terdeteksi ketika melakukan kecurangan (Capability to handle stress to commit fraud) terhadap Salah Kelola Aset Tetap

Dalam melakukan penipuan seorang penipu membutuhkan keahlian dalam mengelola penipuan selama jangka waktu yang panjang dan bisa mengalami stres. Seseorang yang mengalami tekanan yang cukup kuat dapat mengalami stres, ketika seseorang melakukan suatu tindakan kecurangan/ penipuan maka orang itu harus bisa menyembunyikan, atau menangani rasa stres yang dialami dalam jangka waktu cukup lama. Terdapat resiko terdeteksi dengan konsekuensi pribadi dan juga sebagai kebutuhan konstan untuk menyembunyikan penipuan pada setiap hari. Orang tersebut juga harus secara efektif dan konsisten berbohong untuk menghindari deteksi dan bahkan juga harus membujuk orang lain untuk percaya bahwa penipuan tidak terjadi (Wolfe dan Hermanson, 2004). Hasil penelitian Shelton (2014) meneliti pengaruh elemen kemampuan terhadap penyalahgunaan aset, hasilnya menunjukkan bahwa unsur kapabilitas menangani stres yang dalam penelitian tersebut dibandingkan dengan paksaan dan penipuan mempunyai pengaruh yang signifikan terhadap kemampuan seseorang dalam melakukan penyalahgunaan aset.

H11: Faktor kemampuan menangani stres dan resiko terdeteksi ketika 
seseorang melakukan tindakan kecurangan (capability to handle stress to commit fraud) berpengaruh positif terhadap salah kelola aset tetap.

\section{Hipotesis penelitian}

Pengaruh Tekanan Keuangan (Financial Pressure) terhadap Salah

\section{Kelola Aset Tetap}

Menurut teori Fraud

Diamond, tekanan keuangan (financial pressure) merupakan faktor tekanan yang berasal dari masalah keuangan seseorang diantaranya adalah: tekanan keuangan ini dapat mendorong seseorang untuk melakukan tindakan kecurangan, karena desakan kebutuhan keuangan yang harus segera diselesaikan. Menurut Albrecht, Kranacher dan Albrecht. (2008) tekanan yang dirasakan bisa muncul karena banyak hal yang terjadi tekanan ini bisa dirasakan oleh seseorang saja atau beberapa orang atau bahkan satu entitas organisasi. Widarti (2015) dalam laporan penelitiannya tentang pengaruh tekanan, terhadap kemungkinan kecurangan keuangan menyatakan bahwa tekanan yang diproksi dengan perubahan total aset, Return Of Assets (ROA), total arus kas mempunyai pengaruh terhadap kemungkinan tindakan kecurangan laporan keuangan. Menurut Murdiansyah dan Nurkholis (2017) yang meneliti pengaruh tekanan terhadap perilaku kecurangan akademik mahasiswa menunjukkan bahwa tekanan mempunyai pengaruh signifikan dan positif terhadap kecenderungan kecurangan akademik oleh mahasiswa dan Wibowo (2017) tekanan berpengaruh positif terhadap penyalahgunaan aset.

H1: Faktor tekanan kondisi keuangan (financial pressure) berpengaruh positif terhadap salah kelola aset tetap.

\section{Pengaruh Tekanan Kebiasaan (Vice Pressure) terhadap Salah Kelola Aset Tetap}

Berdasarkan teori Fraud Diamond, tekanan kebiasaan (vice pressure) merupakan faktor tekanan yang berasal dari masalah kebiasaan yang dilakukan seseorang. Faktor tekanan non keuangan/ faktor kebiasaan antara lain: kebiasaan seseorang untuk berjudi (gambling), obat-obatan terlarang (drugs) dan seseorang yang memiliki kebiasaan sebagai peminum minuman beralkohol (alcoholic) serta hubungan diluar 
pernikahan (extra marital relationship) (Albrecht dkk., 2011). Hasil penelitian Pamungkas (2015) tekanan akademik mempunyai pengaruh positif terhadap sikap/ tindakan kecurangan akademik pada siswa. Sedangkan menurut penelitian Irphani (2017) terdapat pengaruh yang signifikan positif antara variabel tekanan terhadap fraud di sektor pemerintahan.

$\mathrm{H} 2$ : Faktor tekanan kebiasaan (vice pressure) berpengaruh positif terhadap salah kelola aset tetap.

\section{Pengaruh Tekanan Hubungan}

Pekerjaan (Work Related Pressure) terhadap Salah Kelola Aset Tetap

Menurut Albrecht dkk. (2011).tekanan hubungan pekerjaan juga mempengaruhi seseorang dalam melakukan tindakan fraud, hal ini biasanya berupa beberapa faktor yaitu: keinginan agar kinerja seseorang lebih mendapatkan pengakuan, seseorang merasa takut apabila suatu saat akan kehilangan pekerjaan atau seseorang memiliki keinginan untuk mendapatkan promosi jabatan. Penelitian sejenis juga dilakukan oleh Irphani (2017) yang meneliti pengaruh tekanan, kesempatan, rasionalisasi dan kemampuan terhadap tindakan fraud dalam institusi pemerintahan. Hasil penelitiannya diperoleh kesimpulan bahwa tekanan berpengaruh positif terhadap fraud di sektor pemerintahan. Penelitian sejenis juga dilakukan oleh Murdiansyah and Nurkholis (2017) menunjukkan bahwa tekanan mempunyai pengaruh signifikan dan positif terhadap kecenderungan kecurangan akademik oleh mahasiswa. H3: Faktor tekanan hubungan pekerjaan (work related pressure) berpengaruh positif terhadap salah kelola aset tetap.

\section{Pengaruh Tekanan Lainnya (Other} Pressure) terhadap Salah Kelola Aset Tetap

Menurut Albrecht dkk. (2011) tekanan dorongan lainnya juga merupakan salah satu penyebab seseorang melakukan tindakan fraud. Tekanan lainnya biasanya berupa pemikiran seseorang untuk membobol sistem yang sudah ada, selain itu adalah keinginan seseorang untuk menciptakan penampilan sukses, faktor lainnya adalah egoisme, kekuasaan dan kontrol, serta penyebab 
lainnya. Sesuai dengan teori Fraud Diamond semakin tinggi tekanan karena faktor lain maka semakin besar pula dorongan bagi seseorang untuk melakukan tindakan kecurangan (Albrecht, Kranacher dan Albrecht., 2008). Temuan (Marliani dan Jogi, 2015) menyebutkan bahwa tekanan yang berasal dari faktor lain dapat berasal dari diri pelaku misalnya keinginan untuk aktualisasi diri, maupaun keinginan untuk merusak/ membobol sistem yang sudah ada dapat mendorong seseorang melakukan asset misappropriation. Purnamasari and Okotroza (2015) meneliti pengaruh tekanan, kesempatan, rasionalisasi dan kesempatan terhadap penyalahgunaan aset oleh karyawan BUMN. Hasilnya adalah faktor tekanan berpengaruh positif terhadap terjadinya tindakan penyalahgunaan aset oleh karyawan BUMN. Penelitian sejenis juga dilakukan oleh Murdiansyah and Nurkholis (2017) menunjukkan bahwa tekanan mempunyai pengaruh signifikan dan positif terhadap kecenderungan kecurangan akademik oleh mahasiswa.
H4: Faktor tekanan lainnya (other pressure) berpengaruh positif terhadap salah kelola aset tetap.

\section{Pengaruh Persepsi Peluang/ Kesempatan untuk melakukan kecurangan (Perceived Opportunities to commit fraud) terhadap Salah} Kelola Aset Tetap

Menurut Cressey kesempatan (opportunity) mencakup segala sesuatu yang membentuk keyakinan pelaku kecurangan untuk dapat melakukan kecurangan dan tidak akan tertangkap, kalaupun dia tertangkap tidak akan ada sesuatu yang serius menimpanya. Penelitian lain dilakukan oleh Pamungkas (2015) meneliti pengaruh tekanan, kesempatan dan rasionalisasi terhadap kecurangan akademik oleh para siswa. Hasilnya menyatakan bahwa peluang berpengaruh positif terhadap kecurangan akademik. Penelitian Zahara (2017) mengungkapkan bahwa faktor kesempatan berpengaruh positif dan signifikan terhadap tindakan kecurangan (fraud) yang dilakukan oleh narapidana lembaga pemasyarakatan kelas IIa di Kota Pekanbaru. Penelitian sebelumnya dilakukan oleh Parlindungan (2015) 
yang meneliti pengaruh faktor tekanan, kesempatan (opportunity) diproksi dengan RPT dan rasionalisasi terhadap financial statement fraud yang hasilnya menunjukkan bahwa tekanan berpengaruh positif terhadap financial statement fraud dan penelitian Wibowo (2017) kesempatan berpengaruh positif terhadap penyalahgunaan aset.

H5: Faktor persepsi peluang (perceived opportunities) berpengaruh positif terhadap salah kelola aset tetap.

\section{Pengaruh Otorisasi Posisi untuk} melakukan kecurangan (Position Authorization to commit fraud) terhadap Salah Kelola Aset Tetap

Kemampuan ini merupakan situasi yang memiliki ciri-ciri yang diperlukan atau ketrampilan dan kemampuan bagi seseorang untuk melakukan penipuan. Menurut Albrecht, Kranacher dan Albrecht (2008) hanya orang yang mempunyai kapasitas yang sangat tinggi lebih dapat memahami pengendalian internal yang ada, untuk mengidentifikasi kelemahan dan menggunakannya dalam perencanaan pelaksanaan penipuan. Menurut hasil penelitian Ruankaew (2016) diperoleh hasil bahwa kemampuan menjadikan pintu masuk bagi seseorang dalam melakukan penipuan. Penelitian Purnamasari dan Okotroza (2015) hasilnya menunjukkan bahwa faktor kemampuan berpengaruh positif terhadap terjadinya penyalahgunaan aset oleh karyawan BUMN.

H7: Faktor otorisasi posisi untuk melakukan kecurangan (position authorization to commit fraud) berpengaruh positif terhadap salah kelola aset tetap.

Pengaruh Kecerdasan untuk melakukan kecurangan (Intelligence to commit fraud) terhadap Salah Kelola Aset Tetap

Kecerdasan dan kreativitas penipu adalah seseorang yang mengerti dan mampu memanfaatkan lemahnya sistem pengendalian internal serta menggunakan otorisasi posisi, fungsi maupun akses kewenangan untuk mengambil keuntungan yang lebih besar, Abdullahi and Mansor (2015) dan Shelton (2014) meneliti pengaruh elemen kemampuan terhadap penyalahgunaan aset, hasilnya menunjukkan bahwa unsur 
kecerdasan pada elemen kapabilitas/ kemampuan yang dalam penelitian tersebut membandingkan antara kecerdasan dan keyakinan menunjukkan pengaruh yang signifikan terhadap kemampuan seseorang dalam penyalahgunaan aset. H8: Faktor kecerdasan untuk melakukan kecurangan (intelligence to commit fraud) berpengaruh positif terhadap salah kelola aset tetap.

\section{Pengaruh Egoisme dan Keyakinan untuk melakukan kecurangan (Ego} and Confidence to commit fraud) terhadap Salah Kelola Aset Tetap

$$
\text { Menurut Wolfe dan }
$$

Hermanson (2004) sebagian penipu menemukan diri mereka sukses dalam kejahatan ini, mereka mulai mendapatkan beberapa hal yang menyenangkan dalam pengetahuan bahwa mereka bisa membodohi dunia, bahwa mereka menunjukkan superioritas mereka kepada orang lain. Penelitian sebelumnya dilakukan oleh Manurung dan Hardika (2015) yang meneliti tentang elemen tekanan, kesempatan, rasionalisasi dan elemen kemampuan terhadap kecurangan pelaporan keuangan. Hasilnya menunjukkan bahwa elemen kemampuan yang diproksi dengan perputaran direksi mempunyai pengaruh yang signifikan dan positif kepada tindakan kecurangan pelaporan keuangan.

H9: Faktor ego dan keyakinan untuk melakukan kecurangan (ego and confidence to commit fraud) berpengaruh positif terhadap salah kelola aset tetap.

Pengaruh Kemampuan Menangani Stres dan resiko terdeteksi ketika melakukan kecurangan (Capability to handle stress to commit fraud) terhadap Salah Kelola Aset Tetap

Menurut teori Fraud Diamond, karakteristik lain yang kuat dari penipu adalah kemampuan mereka untuk menangani stress (Wolfe dan Hermanson, 2004). Dalam melakukan penipuan seorang penipu membutuhkan keahlian dalam mengelola penipuan selama jangka waktu yang panjang dan bisa mengalami stres. Hasil penelitian Shelton (2014) meneliti pengaruh elemen kemampuan terhadap penyalahgunaan aset, hasilnya menunjukkan bahwa unsur kapabilitas menangani stres yang dalam penelitian tersebut dibandingkan dengan paksaan 
dan penipuan mempunyai pengaruh yang signifikan terhadap kemampuan seseorang dalam melakukan penyalahgunaan aset. Hasil penelitian Nursani dan Irianto (2014) menunjukkan pengaruh elemen tekanan, peluang, elemen rasionalisasi serta kemampuan kepada perilaku kecurangan akademik. Hasilnya disimpulkan bahwa kemampuan (capability) mempunyai pengaruh yang positif signifikan terhadap tindakan kecurangan akademik.

H11: Faktor kemampuan menangani stres dan resiko terdeteksi ketika seseorang melakukan tindakan kecurangan (capability to handle stress to commit fraud) berpengaruh positif terhadap salah kelola aset tetap.

\section{METODE PENELITIAN}

$$
\text { Populasi dalam }
$$

penelitian ini adalah perangkat daerah di Kabupaten Semarang Jawa Tengah. Metode pengumpulan data yang digunakan adalah metode survey yang merupakan metode utama pengumpulan data dengan memberikan pertanyaan kepada responden individu. Pengukuran dalam penelitian ini menggunakan skala likert lima poin. Jawaban skor mulai dari 1 sampai dengan 5, dimana 1 adalah sangat tidak setuju, 2 tidak setuju, 3 netral, 4 setuju, dan 5 sangat setuju. Sebanyak 337 kuesioner di sebar untuk 46 organisasi perangkat daerah dan 296 kuesioner kembali dan dapat digunakan, dengan respon rate sebesar $87 \%$. Analisa data untuk penelitian ini menggunakan bantuan alat analisa SPSS 2.2.

\section{HASIL DAN PEMBAHASAN \\ Data Penelitian}

\section{Gambaran Umum Objek Penelitian}

Kuesioner disebarkan kepada Perangkat Daerah yang ada di Pemerintah Kabupaten Semarang sejumlah 337 buah kuesioner yang dibagikan secara proporsional ke seluruh OPD, dengan rincian setiap pejabat struktural pada OPD diberikan kuesioner yang ditujukan kepada seluruh Pejabat Struktural, Pengguna Barang, Penyimpan Barang dan untuk Pengurus Barang. Kuesioner diberikan kepada ketiga jabatan tersebut karena dianggap sebagai pihak yang dapat memberikan informasi terkait pengelolaan barang milik daerah pada organisasi perangkat daerah serta pejabat struktural sebagai pihak yang terlibat dalam pemanfaatan barang 
milik daerah. Waktu yang dibutuhkan untuk pengisian dan pengambilan kuesioner adalah kurang lebih 2 minggu, yaitu mulai tanggal 24 April 2017 s.d 14 Mei 2017. Pada kurun waktu tersebut kuesioner yang dikirimkan kepada 46 Perangkat Daerah kembali sebanyak 296 buah (87\%). Adapun ringkasan distribusi kuesioner dalam penelitian ini dapat dilihat dalam tabel 1.

Tabel 1

Ringkasan Pengiriman dan Pengembalian Kuesioner

\begin{tabular}{lc}
\multicolumn{1}{c}{ Uraian } & Jumlah \\
\hline Kuesioner yang telah dikirimkan (46 OPD) & 337 buah \\
Kuesioner yang telah kembali & 296 buah \\
Kuesioner yang tidak dapat digunakan & 0 \\
Kuesioner yang dapat digunakan & 296 buah \\
Tingkat pengembalian atau response rate & $87 \%$ \\
Tingkat pengembalian kuesioner yang dapat & \\
digunakan (usable response rate) & $87 \%$
\end{tabular}

Sumber: Data diolah, 2018

\section{Data Deskriptif Responden}

berikut ini disajikan data demografi responden, sebagimana disajikan dalam tabel 2:

Tabel 2

Demografi Responden

\begin{tabular}{rccr}
\hline Uraian & Kriteria & Jumlah & Prosentase \\
\hline \multirow{2}{*}{ Jenis kelamin } & Pria & 180 & $60,81 \%$ \\
& Wanita & 116 & $39,18 \%$ \\
\hline \multirow{2}{*}{ Usia } & $25-35$ Tahun & 35 & $11,82 \%$ \\
& $35-45$ Tahun & 117 & $39,53 \%$ \\
& $45-58$ Tahun & 144 & $48,65 \%$ \\
\hline
\end{tabular}




\begin{tabular}{|c|c|c|c|}
\hline & SMA & 28 & $9,45 \%$ \\
\hline \multirow{3}{*}{ Pendidikan } & Diploma & 24 & $8,10 \%$ \\
\hline & S1 & 148 & $50 \%$ \\
\hline & $\mathbf{S 2}$ & 96 & $32,43 \%$ \\
\hline \multirow{5}{*}{$\begin{array}{l}\text { Masa kerja } \\
\text { keseluruhan }\end{array}$} & 0 - 5 tahun & 17 & $5,74 \%$ \\
\hline & 5 - 10 tahun & 54 & $18,24 \%$ \\
\hline & 10 - 15 tahun & 99 & $33,45 \%$ \\
\hline & & & \\
\hline & $>15$ tahun & 126 & $42,57 \%$ \\
\hline \multirow{6}{*}{ Jabatan } & Pengguna Barang & 32 & $10,81 \%$ \\
\hline & & 42 & $14,19 \%$ \\
\hline & Barang & & \\
\hline & Pengurus Barang & 41 & $1385 \%$ \\
\hline & Pejabat & 181 & \\
\hline & Struktural & & \\
\hline \multirow{4}{*}{$\begin{array}{c}\text { Lama menduduki } \\
\text { jabatan }\end{array}$} & 0 - 5 tahun & 107 & $36,14 \%$ \\
\hline & 5 - 10 tahun & 111 & $37,51 \%$ \\
\hline & 10 - 15 tahun & 62 & $20,94 \%$ \\
\hline & > 15 Tahun & 16 & $5,41 \%$ \\
\hline
\end{tabular}

\section{Sumber: Data diolah 2018}

Berdasarkan data demografi responden dapat dilihat bahwa jumlah total responden sebanyak 296, yang terdiri dari 180 orang berjenis kelamin laki-laki atau sebanyak $60,81 \%$, dan selebihnya sejumlah 116 orang atau $39,18 \%$ berjenis kelamin perempuan. Mayoritas responden berusia diantara 46 sampai 58 tahun sebesar 144 orang $(48,65 \%)$, sementara responden yang berusia 36-45 sebanyak 117 orang
$(39,53 \%)$, usia diantara $25-35$ tahun sebanyak 35 orang $(11,82 \%)$. Sebagian besar responden memiliki tingkat pendidikan Strata 1 (S1) sebanyak 148 orang (50\%), kemudian SMA sebanyak 28 orang $(9,45 \%)$, S2 sebanyak 96 orang $(32,43 \%)$ dan sisanya berpendidikan Diploma sebanyak 23 orang $(8,10 \%)$. Masa kerja dalam jabatan responden 0 sampai dengan 5 tahun sejumlah 107 
pegawai (36,14\%), 5 hingga 10 tahun adalah sejumlah 111 pegawai $(37,51 \%), \quad 10$ hingga 15 tahun sejumlah 62 orang pegawai atau 20,94\% serta masa kerja lebih dari 15 tahun sejumlah 16 orang pegawai $(5,41)$.

\section{Analisa Data}

\section{Uji Statistik Deskriptif}

Berikut ini adalah hasil statistik deskriptif pada variabel penelitian sebagaimana disajikan dalam tabel 3:

Tabel 3

Statistik Deskriptif Variabel Penelitian

\begin{tabular}{rlcccccc}
\hline \multirow{2}{*}{ No } & \multicolumn{1}{c}{ Variabel } & N & \multicolumn{2}{c}{ Kisaran } & \multicolumn{2}{c}{ Rata-Rata } & Standar \\
& & & Teoritis & Aktual & Teoritis & Aktual & Deviasi \\
\hline 1 & Salah Kelola Aset Tetap & 296 & $3-15$ & $3-6$ & 9 & 6.02 & 2.3 \\
2 & Tekanan keuangan & 296 & $4-20$ & $3-10$ & 9 & 6.21 & 2.5 \\
3 & Tekanan Kebiasaan & 296 & $3-15$ & $4-8$ & 12 & 7.62 & 4.0 \\
& Tekanan Hubungan & & & & & & \\
4 & Pekerjaan & 296 & $3-15$ & $3-6$ & 9 & 6.4 & 2.3 \\
5 & Tekanan Lainnya & 296 & $3-15$ & $3-6$ & 9 & 6.5 & 2.5 \\
6 & Persepsi Kesempatan & 296 & $3-15$ & $3-6$ & 9 & 7.3 & 3.0 \\
7 & Rasionalisasi Umum & 296 & $2-10$ & $3-10$ & 9 & 6.3 & 2.0 \\
8 & Otorisasi Posisi & 296 & $2-10$ & $2-8$ & 6 & 5.2 & 2.0 \\
9 & Kecerdasan & 296 & $2-10$ & $2-8$ & 6 & 5.1 & 2.0 \\
10 & Ego dan Keyakinan & 296 & $2-10$ & $2-7$ & 6 & 5.1 & 2.0 \\
11 & Paksaan dan Penipuan & 296 & $2-10$ & $2-7$ & 6 & 4.6 & 2.0 \\
& Kemampuan Menangani & & & & & &
\end{tabular}

Sumber: Data diolah, 2018 
Pengujian Asumsi Klasik

Hasil uji asumsi klasik atas model penelitian menunjukkan bahwa tidak terdapat permasalahan pada gejala

multikolinieritas, heterokedastisitas, normalitas pada model penelitian.

Tabel 4

Ringkasan Hasil Pengujian Asumsi Klasik

\begin{tabular}{|c|c|c|c|}
\hline $\begin{array}{c}\text { Uji Asumsi } \\
\text { Klasik }\end{array}$ & $\begin{array}{c}\text { Variabel } \\
\text { Penelitian }\end{array}$ & Sig & VIF \\
\hline Normalitas & & 0,167 & \\
\hline \multirow{11}{*}{ Multikolinieritas } & FP & & 1,530 \\
\hline & VP & & 2,232 \\
\hline & WP & & 1,879 \\
\hline & $\mathrm{OP}$ & & 2,409 \\
\hline & $\mathrm{PO}$ & & 1,692 \\
\hline & $\mathrm{CR}$ & & 1,356 \\
\hline & AP & & 3,024 \\
\hline & I & & 2,998 \\
\hline & $\mathrm{EC}$ & & 1,506 \\
\hline & $\mathrm{CD}$ & & 1,862 \\
\hline & AS & & 1,396 \\
\hline \multirow{10}{*}{ Heterokedastisitas } & FP & 0,596 & \\
\hline & VP & 0,551 & \\
\hline & WP & 0,717 & \\
\hline & $\mathrm{OP}$ & 0,728 & \\
\hline & $\mathrm{PO}$ & 0,746 & \\
\hline & CR & 0,372 & \\
\hline & AP & 0,856 & \\
\hline & I & 0,526 & \\
\hline & $\mathrm{EC}$ & 0,533 & \\
\hline & $\mathrm{CD}$ & 0,151 & \\
\hline
\end{tabular}




\begin{tabular}{cccc}
\hline $\begin{array}{c}\text { Uji Asumsi } \\
\text { Klasik }\end{array}$ & $\begin{array}{c}\text { Variabel } \\
\text { Penelitian }\end{array}$ & Sig & VIF \\
\hline CS & 0,365 \\
\hline
\end{tabular}

\section{Sumber : Olah Data SPSS, 2018}

\section{Pengujian Regresi Linier Berganda}

Analisis pada regresi linear berganda

dipakai agar mengetahui pengaruh antara variabel indpenden terhadap variabel dependen.

Tabel 5

Rekapitulasi Uji pada Regresi Linear Berganda

\begin{tabular}{cccc}
\hline Nilai F & Nilai R & Adj $\mathbf{R}^{2}$ & Sig \\
\hline 22,005 & 0,678 & 0,439 & 0,000 \\
\hline \multicolumn{3}{c}{ Uji t (t-test) } \\
\hline Variabel Bebas & Koefisien & Nilai t & Sig \\
\hline FP & regresi & 2,164 & 0,031 \\
VP & 0,117 & 2,776 & 0,006 \\
WP & 0,181 & 2,275 & 0,024 \\
OP & 0,136 & 2,752 & 0,006 \\
PO & 0,186 & 0,407 & 0,684 \\
CR & 0,023 & 3,139 & 0,002 \\
AP & 0,159 & 0,142 & 0,887 \\
I & 0,011 & 0,083 & 0,934 \\
EB & 0,006 & $-0,01$ & 0,985 \\
CD & $-0,001$ & 2,560 & 0,011 \\
AS & 0,152 & $-2,975$ & 0,003
\end{tabular}

Sumber : Olah data SPSS, 2018 


\section{Uji F (Goodness of Fit)}

Koefisien 0,678, oleh karena R tidak memiliki negasi untuk menolak atau menerima hipotesis penelitian, maka diperlukan transformasi koefisien regresi berganda $\mathrm{R}$ ke dalam uji F. Dengan kata lain Tekanan Keuangan/Finansial (FP); Tekanan Kebiasaan (VP); Tekanan Hubungan Pekerjaan (WP); Tekanan lainnya (OP); Persepsi Kesempatan (OP); Rasionalisasi Umum (CR); Otorisasi Posisi (AP); Kecerdasan (I); Ego \& Keyakinan (EC); Paksaan \& Penipuan (CD); dan Kemampuan Menangani Stres (CS) secara simultan berpengaruh signifikan terhadap variabel Salah Kelola Aset Tetap (AM).

\section{Koefisien Determinasi ( $\mathbf{R}^{2}$ )}

Koefisien determinasi perlu dilakukan guna menentukan besar pengaruh variabel independen dapat menjelaskan variabel dependen (Ghozali, 2013). Berdasarkan tabel 4.6 di atas juga dilihat pengaruh kesebelas variabel bebas terhadap variabel Salah Kelola Aset Tetap dengan nilai Adjusted $R^{2}$, yaitu 0,439 atau 43,9 persen. Hal ini berarti, sebesar 43,9 persen variasi yang terjadi pada variabel Salah Kelola Aset Tetap disebabkan oleh pengaruh dari variabel Tekanan Keuangan (FP); Tekanan Kebiasaan (VP); Tekanan hubungan pekerjaan (WP); Tekanan Lainnya (OP); Persepsi Peluang (PO); Rasionalisasi Umum (CR); Otorisasi Posisi (AP); Kecerdasan (I); Ego \& Keyakinan (EC); Paksaan \& Penipuan (CD); dan Kemampuan Menangani Stres (CS) secara simultan. Dengan demikian masih terdapat sebesar $100 \%$ - $43,9 \%=56,1$ persen yang merupakan kontribusi variabel bebas lain di luar variabel independen secara simultan.

\section{Persamaan Linear Berganda}

Analisis regresi linier berganda digunakan untuk mengetahui pengaruh anatara variabel independen terhadap variabel dependen. Persamaan regresi linear berganda penelitian adalah sebagai berikut:

$$
\begin{aligned}
& \mathrm{Y}=0,117 \mathrm{FP}+0,181 \mathrm{VP}+0,136 \mathrm{WP} \\
& +0,186 \mathrm{OP}+0,02 \mathrm{PO}+0,159 \mathrm{CR}+ \\
& \text { 0,011AP }+0,006 \mathrm{I}-0,001 \mathrm{EC}+ \\
& \text { 0,152CD }-0,153 \mathrm{CS}
\end{aligned}
$$

\section{Pengujian Hipotesis}


Hipotesis merupakan jawaban atau dugaan yang bersifat sementara untuk menjawab apa yang dirumuskan dalam masalah.
Secara umum berdasarkan hasil pengolahan data sebanyak 11 (sebelas) variabel pengujian hipotesis berikut ini:

Tabel 6

\section{Ringkasan Hasil Uji Hipotesis}

\section{Hipotesis}

Tekanan keuangan berpengaruh positif terhadap salah kelola aset tetap(FP)

Tekanan kebiasaan berpengaruh positif terhadap salah kelola aset tetap (VP)

Tekanan hubungan pekerjaan berpengaruh positif terhadap salah kelola aset tetap (WP)

Tekanan faktor lain berpengaruh positif terhadap salah kelola aset tetap (OP)

Persepsi peluang berpengaruh positif terhadap salah kelola aset tetap (PO)

Rasionalisasi umum berpengaruh positif terhadap salah kelola aset tetap (CR)

Otorisasi posisi berpengaruh positif terhadap salah kelola aset tetap (AP)

Kecerdasan berpengaruh positif terhadap salah kelola aset tetap (I)

Ego dan keyakinan berpengaruh positif terhadap salah kelola aset tetap (EC)

Paksaan dan penipuan berpengaruh positif terhadap salah kelola aset tetap (CD)

Kemampuan menangani stres berpengaruh positif terhadap salah kelola aset tetap (CS)

\section{Sumber: Data output SPSS, 2018}

Hasil Uji Hipotesis

H1 diterima

$\mathrm{H} 2$ diterima

H3 diterima

H4 diterima

H5 ditolak

H6 diterima

H7 ditolak

H8 ditolak

H9 ditolak

H10 diterima

H11 ditolak 


\section{Pembahasan}

\section{Pengaruh Tekanan Keuangan}

(Financial Pressure) terhadap salah

\section{kelola asset tetap}

Berdasarkan hasil pengujian hipotesis diperoleh hasil bahwa pengaruh tekanan keuangan berengaruh positif dan signifikan terhadap salah kelola aset tetap. Data deskriptif variabel yang disajikan dalam tabel 4.3, didapatkan bahwa kisaran jawaban responden (kisaran aktual) berada pada rentang 3-10 sedangkan kisaran teoritis berada dalam rentang 4-20. Rata-rata aktual didapatkan nilai sebesar 6.21 lebih rendah dari rata-rata teoritisnya yaitu berada pada nilai 9.00. Nilai standar deviasi atas jawaban responden didapatkan nilai sebesar 2.5 yang berarti bahwa penyimpangan terhadap rata-rata tekanan keuangan sebesar \pm 2.5 (tabel 4.3). Temuan ini sesuai dengan penelitian yang dilakukan Albrecht dkk. (2011) tentang pengaruh tekanan terhadap tindakan kecurangan, sehingga semakin mendukung dengan teori penipuan berlian atau Fraud Diamond yang dikemukakan oleh Wolfe dan Hermanson (2004)
Penelitian ini juga sejalan dengan temuan, Pamungkas (2015), Nursani dan Irianto (2014), Purnamasari dan Okotroza (2015), Ekadah (2016) dan Wibowo (2017) yang menunjukkan bahwa tekanan keuangan berpengaruh positif dan signifikan terhadap tindakan kecurangan berupa penyalahgunaan aset (asset misappropriation).

Pengaruh Tekanan Kebiasaan (Vice Pressure) terhadap Salah Kelola Aset Tetap

Berdasarkan hasil uji hipotesis diperoleh hasil bahwa tekanan kebiasaan berpengaruh positif dan siginifikan terhadap salah kelola aset tetap. Sedangkan data deskriptif variabel yang disajikan dalam tabel 4.3, didapatkan bahwa kisaran jawaban responden (kisaran aktual) berada pada rentang 4-8 sedangkan kisaran teoritis berada dalam rentang 3-15. Rata-rata/mean aktual didapatkan nilai sebesar 7.62 lebih rendah dari mean teoritisnya yaitu berada pada nilai 12.00. Nilai standar deviasi atas jawaban responden didapatkan nilai sebesar 4.00 yang 
berarti bahwa penyimpangan terhadap rata-rata tekanan kebiasaan sebesar \pm 4.00 (tabel 4.3). Temuan ini sejalan dengan penelitian Skousen, Wright dan Smith (2009) dan Widarti (2015) dimana faktor tekanan berpengaruh positif terhadap asset misappropriation. Penelitian Widarti (2015) juga menunjukkan bahwa tekanan stabilitas keuangan mempunyai pengaruh positif terhadap tindakan kecurangan laporan keuangan.

\section{Pengaruh Tekanan Hubungan}

Pekerjaan (Work Related Pressure) terhadap Salah Kelola Aset Tetap

Berdasarkan pengujian hipotesis diperoleh hasil bahwa tekanan hubungan pekerjaan berpengaruh positif dan signifikan terhadap salah kelola aset tetap. Sedangkan data deskriptif variabel yang disajikan dalam tabel 4.3, didapatkan bahwa kisaran jawaban responden (kisaran aktual) berada pada rentang 3-6 sedangkan kisaran teoritis berada dalam rentang 3-15. Mean aktual didapatkan nilai sebesar 6.40 lebih rendah dari mean teoritisnya yaitu berada pada nilai 9.00. Nilai standar deviasi atas jawaban responden didapatkan nilai sebesar 2.30 yang berarti bahwa penyimpangan terhadap rata-rata tekanan hubungan pekerjaan sebesar \pm 2.30 (tabel 4.3). Hasil ini sesuai dengan temuan dari Ekadah (2016) dan Irphani (2017) yang hasilnya menunjukkan bahwa tekanan yang berhubungan dengan pekerjaan yang diproksikan dengan keefektifan SPI yang mempunyai pengaruh positif terhadap terjadinya tindakan fraud pada sektor pemerintahan.

Pengaruh Tekanan Karena Faktor Lain (Other Pressure) terhadap

\section{Salah Kelola Aset Tetap}

Berdasarkan hasil pengujian hipotesis dieroleh hasil bahwa tekanan karena factor lainnya berpengaruh positif dan signifikan terhadap salah kelola aset tetap. Berdasarkan data deskriptif variabel yang disajikan dalam tabel 4.3, didapatkan bahwa kisaran jawaban responden (kisaran aktual) berada pada rentang 3-6 sedangkan kisaran teoritis berada dalam rentang 3-15. Mean aktual didapatkan nilai sebesar 6.50 lebih rendah dari mean teoritisnya yaitu berada pada nilai 9.00. Nilai standar deviasi atas jawaban responden 
didapatkan nilai sebesar 2.50 yang berarti bahwa penyimpangan terhadap rata-rata tekanan karena faktor lainnya sebesar \pm 2.50 (tabel 4.3). Penelitian ini sejalan dengan temuan Marliani dan Jogi (2015) dan Purnamasari dan Okotroza (2015) bahwa tekanan yang berasal dari faktor lain dapat dapat berasal dari diri pelaku misalnya keinginan untuk aktualisasi diri, maupun keinginan untuk merusak/ membobol sistem yang sudah ada dapat mendorong seseorang melakukan asset misappropriation .

\section{Pengaruh Persepsi Kesempatan untuk melakukan kecurangan (Perceived Opportunity to commit fraud) terhadap Salah Kelola Aset Tetap}

Berdasarkan hasil pengujian hipotesis diperoleh hasil bahwa persepsi kesempatan tidak berpengaruh terhadap salah kelola aset tetap. Data deskriptif variabel yang disajikan dalam tabel 4.3, didapatkan bahwa kisaran jawaban responden (kisaran aktual) berada pada rentang 3-6 sedangkan kisaran teoritis berada dalam rentang 3-15. Mean aktual didapatkan nilai sebesar 7.30 lebih rendah dari mean teoritisnya yaitu berada pada nilai 9.00. Nilai standar deviasi atas jawaban responden didapatkan nilai sebesar 3.00 yang berarti bahwa penyimpangan terhadap rata-rata persepsi kesempatan untuk melakukan kecurangan sebesar \pm 3.00 (tabel 4.3).Penyebab rendahnya jawaban responden ini dapat dipengaruhi beberapa faktor, diantaranya adalah pelaku kecurangan salah kelola aset kemungkinan sudah memahami deteksi yang dilakukan auditor eksternal seperti KPK, BPK dll, sehingga ada kecenderungan pelaku salah kelola aset menggunakan jenis/ bentuk kesempatan yang berbeda yang tidak pernah dilakukan oleh pelaku kecurangan pada umumnya agar tindakan mereka sulit terdeteksi. Temuan ini bertentangan dengan penelitian Albrecht dkk. (2011) yaitu kesempatan dapat mendukung seseorang untuk melakukan tindakan kecurangan yang dalam hal ini berupa salah kelola aset, sehingga penelitian ini tidak dapat dijelaskan oleh Teori Fraud Diamond dimana kesempatan merupakan faktor penyebab seseorang untuk melakukan tindakan kecurangan seperti yang 
dikemukakan oleh Wolfe dan Hermanson (2004). Selain itu juga tidak sejalan dengan temuan Purnamasari dan Okotroza (2015), Purwanto dkk. (2016) serta Wibowo (2017) dimana kesempatan berpengaruh positif terhadap penyalahgunaan aset.

\section{Pengaruh Rasionalisasi Umum} untuk melakukan kecurangan (Common Rasionalization to commit fraud) terhadap Salah Kelola Aset Tetap

Berdasarkan hasil pengujian hipotesis diperoleh hasil bahwa rasionalisasi umum berpengaruh positif dan signifikan terhadap salah kelola aset tetap. Dari data deskriptif variabel yang disajikan dalam tabel 4.3, didapatkan bahwa kisaran jawaban responden (kisaran aktual) berada pada rentang 3-10 sedangkan kisaran teoritis berada dalam rentang 2-10. Mean aktual didapatkan nilai sebesar 6.30 lebih rendah dari mean teoritisnya yaitu berada pada nilai 9.00. Nilai standar deviasi atas jawaban responden didapatkan nilai sebesar 2.00 yang berarti bahwa penyimpangan terhadap rata-rata rasionalisasi umum sebesar \pm 2.00 (tabel 4.3). Menurut Owens (2010) dalam situasi seperti ini tidak semua pelanggaran dapat diatasi atau dikenakan sanksi, sehingga muncul anggapan pembenaran pada para pelaku bahwa pelanggaran juga banyak dilakukan oleh orang lain. Temuan ini sejalan dengan penelitian Pamungkas (2015) dan Purnamasari dan Okotroza (2015) bahwa rasionalisasi berpengaruh positif terhadap penyalahgunaan aset yang dilakukan oleh karyawan.

Pengaruh Otorisasi Posisi untuk melakukan kecurangan (Position Authorization to commit fraud) terhadap Salah Kelola Aset Tetap

Berdasarkan hasil pengujian hipotesis diperoleh hasil bahwa otorisasi posisi tidak berpengaruh terhadap salah kelola aset tetap, sedangkan data deskriptif variabel yang disajikan dalam tabel 4.3, didapatkan bahwa kisaran jawaban responden (kisaran aktual) berada pada rentang 2-8 sedangkan kisaran teoritis berada dalam rentang 2-10. Mean aktual didapatkan nilai sebesar 5.20 lebih rendah dari rata-rata teoritisnya yaitu berada pada nilai 6.00. Nilai standar deviasi atas 
jawaban responden didapatkan nilai sebesar 2.00 yang berarti bahwa penyimpangan terhadap rata-rata otorisasi posisi/fungsi untuk melakukan kecurangan sebesar \pm 2.00 (tabel 4.3). Temuan ini bertentangan dengan hasil temuan penelitian Wolfe dan Hermanson (2004) bahwa kemampuan memungkinan seseorang untuk mengenali pintu atau cara yang terbuka sebagai kesempatan untuk mengambil keuntungan dari itu dan berjalan berulangkali. Kemampuan ini merupakan situasi yang memiliki ciri-ciri yang diperlukan atau ketrampilan dan kemampuan bagi seseorang untuk melakukan penipuan.

\section{Pengaruh Kecerdasan untuk} melakukan kecurangan (Intelligence to commit fraud) terhadap Salah

\section{Kelola Aset Tetap}

Berdasarkan hasil pengujian hipotesis diatas diperoleh hasil bahwa kecerdasan tidak berpengaruh terhadap salah kelola aset tetap, sedangkan data deskriptif variabel yang disajikan dalam tabel 4.3, didapatkan bahwa kisaran jawaban responden (kisaran aktual) berada pada rentang 2-8 sedangkan kisaran teoritis berada dalam rentang 2-10. Rata-rata aktual didapatkan nilai sebesar 5.10 lebih rendah dari rata-rata teoritisnya yaitu berada pada nilai 6.00. Nilai standar deviasi atas jawaban responden didapatkan nilai sebesar 2.00 yang berarti bahwa penyimpangan terhadap rata-rata kecerdasan untuk melakukan kecerdasan sebesar \pm 2.00 (tabel 4.3). Temuan ini bertentangan dengan penelitian Wolfe dan Hermanson (2004) dan tidak dapat dijelaskan melalui teori Fraud Diamond, dimana menurut teori tersebut kecerdasan atau kreativitas penipu adalah seseorang yang mengerti dan mampu memanfaatkan lemahnya sistem pengendalian internal serta menggunakan otorisasi posisi, fungsi maupun akses kewenangan untuk mengambil keuntungan yang lebih besar. Temuan ini juga tidak sejalan dengan temuan oleh Shelton tahun 2014 meneliti pengaruh elemen capability/ kemampuan berupa kecerdasan terhadap penyalahgunaan aset. Hasilnya menunjukkan bahwa unsur kecerdasan pada elemen kapabilitas/ kemampuan yang dalam penelitian tersebut mempunyai 
pengaruh yang signifikan terhadap penyalahgunaan aset oleh karyawan.

Pengaruh Ego dan Keyakinan untuk melakukan kecurangan (Ego and Confidence to commit fraud) terhadap Salah Kelola Aset Tetap

Berdasarkan hasil pengujian hipotesis dieroleh hasil bahwa ego dan keyakinan tidak berpengaruh terhadap salah kelola aset tetap, dan dari data deskriptif variabel yang disajikan dalam tabel 4.3, didapatkan bahwa kisaran jawaban responden (kisaran aktual) berada pada rentang 2-7 sedangkan kisaran teoritis berada dalam rentang 2-10. Rata-rata aktual didapatkan nilai sebesar 5.10 lebih rendah dari rata-rata teoritisnya yaitu berada pada nilai 6.00. Nilai standar deviasi atas jawaban responden didapatkan nilai sebesar 2.00 yang berarti bahwa penyimpangan terhadap rata-rata ego dan keyakinan untuk melakukan kecurangan sebesar \pm 2.00 (tabel 4.3). Temuan ini bertentangan dengan temuan Wolfe dan Hermanson (2004) ditinjau dari teori Fraud Diamond maka pengaruh egoisme dan keyakinan yang seorang pelaku fraud, semakin mudah bagi orang tersebut untuk melakukan tindakan kecurangan. Penelitian sebelumnya dilakukan oleh Manurung dan Hardika (2015) elemen kemampuan yang diproksi dengan perputaran direksi mempunyai pengaruh yang signifikan dan positif kepada tindakan kecurangan pelaporan keuangan.

\section{Pengaruh Paksaan dan Penipuan} untuk melakukan kecurangan (Coercion and Deceit to commit fraud) terhadap Salah Kelola Aset Tetap

Berdasarkan hasil pengujian hipotesis dieroleh hasil bahwa paksaan dan penipuan berpengaruh positif dan signifikan terhadap salah kelola aset tetap, berdasarkan data deskriptif variabel yang disajikan dalam tabel 4.3, didapatkan bahwa kisaran jawaban responden (kisaran aktual) berada pada rentang 2-7 sedangkan kisaran teoritis berada dalam rentang 2-10. Rata-rata aktual didapatkan nilai sebesar 4.60 lebih rendah dari rata-rata teoritisnya yaitu berada pada nilai 6.00. Nilai standar deviasi atas jawaban responden didapatkan nilai sebesar 2.00 yang berarti bahwa penyimpangan terhadap rata-rata paksaan dan penipuan untuk melakukan kecurangan sebesar \pm 2.00 (tabel 4.3). Penelitian ini juga sejalan 
dengan temuan Shelton (2014) bahwa elemen capability/ kemampuan terhadap penyalahgunaan aset. Hasilnya menunjukkan bahwa unsur paksaan pada elemen kapabilitas/ kemampuan untuk melakukan kecurangan yang dalam penelitian tersebut membandingkan antara paksaan dan penipuan mempunyai pengaruh yang signifikan terhadap penyalahgunaan aset oleh karyawan.

\section{Pengaruh Kemampuan Menangani} Stres dan resiko terdeteksi untuk melakukan kecurangan (Capability Handle Stress to commit fraud) terhadap Salah Kelola Aset Tetap

Berdasarkan hasil pengujian hipotesis dieroleh hasil bahwa kemampuan menangani stress dan resiko terdeteksi ketika melakukan kecurangan berpengaruh negatif dan signifikan terhadap salah kelola aset tetap, sedangkan data deskriptif variabel yang disajikan dalam tabel 4.3, didapatkan bahwa kisaran jawaban responden (kisaran aktual) berada pada rentang 2-7 sedangkan kisaran teoritis berada dalam rentang 2-10. Rata-rata aktual didapatkan nilai sebesar 5.30 lebih rendah dari rata-rata teoritisnya yaitu berada pada nilai 6.00. Nilai standar deviasi atas jawaban responden didapatkan nilai sebesar 2.00 yang berarti bahwa penyimpangan terhadap rata-rata kemampuan menangani stres dan resiko terdeteksi ketika melakukan tindakan kecurangan sebesar \pm 2.00 (tabel 4.3). Penelitian ini tidak sejalan dengan Teori Fraud Diamond dimana karakteristik lain yang kuat dari penipu adalah kemampuan mereka untuk menangani stres, Wolfe dan Hermanson (2004) seorang pelaku kecurangan dalam melakukan penipuan membutuhkan keahlian dalam mengelola penipuan selama jangka waktu yang panjang dan bisa mengalami stres. Hasil temuan ini bertentangan dengan temuan Shelton (2014) yang meneliti pengaruh elemen kemampuan terhadap penyalahgunaan aset, hasilnya menunjukkan bahwa unsur kapabilitas/ kemampuan menangani stres mempunyai pengaruh yang signifikan terhadap kemampuan seseorang dalam melakukan penyalahgunaan aset. 


\section{KESIMPULAN DAN SARAN}

\section{Kesimpulan}

Tujuan penelitian ini guna mengetahui bahwa ,tekanan keuangan, tekanan kebiasaan, tekanan hubungan pekerjaan, tekanan faktor lainnya, persepsi peluang untuk melakukan kecurangan, rasionalisasi umum untuk melakukan kecurangan, otorisasi fungsi untuk melakukan kecurangan, kecerdasan untuk melakukan kecurangan, ego dan keyakinan untuk melakukan kecurangan, paksaan dan penipuan untuk melakukan kecurangan serta kemampuan menangani stres dan resiko terdeteksi untuk melakukan kecurangan berpengaruh positif terhadap salah kelola aset tetap.

Selain itu juga untuk mengetahui interaksi antara variabel independen (tekanan faktor lainnya, persepsi peluang untuk melakukan kecurangan, rasionalisasi umum untuk melakukan kecurangan, otorisasi fungsi untuk melakukan kecurangan, kecerdasan untuk melakukan kecurangan, ego dan keyakinan untuk melakukan kecurangan, paksaan dan penipuan untuk melakukan kecurangan serta kemampuan menangani stress dan resiko terdeteksi untuk melakukan kecurangan) terhadap variabel dependen yaitu salah kelola aset tetap. Responden penelitian ini berjumlah 296 pegawai pada 46 OPD di Kab. Semarang.

Temuan dalam penelitian ini semakin memperkuat dukungan bahwa tekanan keuangan, tekanan kebiasaan, tekanan hubungan pekerjaan dan tekanan karena faktor lainnya, rasionalisasi umum, paksaan dan penipuan untuk melakukan kecurangan terhadap salah kelola aset tetap menunjukkan hasil yang signifikan dan pengaruh yang diberikan bersifat positif terhadap niat seseorang yang hendak melakukan tindakan salah kelola aset tetap, hal ini sejalan dengan temuan Albrecht dkk. (2011) dan Wolfe dan Hermanson (2004) sehingga hasil penelitian ini semakin memperkuat teori Fraud Diamond. Sedangkan temuan persepsi kesempatan untuk melakukan kecurangan, kecerdasan untuk melakukan kecurangan, otorisasi posisi untuk melakukan kecurangan, ego dan keyakinan yang besar untuk melakukan kecurangan tidak berpengaruh terhadap tindakan kecurangan berupa salah kelola aset tetap. Sedangkan kemampuan 
menangani stress dan resiko terdeteksi ketika melakukan tindakan kecurangan berpengaruh negative terhadap salah kelola aset tetap. Hasil penelitian ini tidak mendukung temuan Albrecht dkk. (2011) dan Wolfe dan Hermanson (2004) sehingga tidak dapat dijelaskan dengan teori Fraud Diamond.

\section{Implikasi}

Penelitian ini memiliki beberapa potensi kontribusi untuk pemerintah daerah untuk membuat prosedur yang tepat serta pengendalian internak yang dapat mengurangi atau menghilangkan salah kelola aset daerah oleh perangkat daerah. Secara teoritis hasil penelitian ini diharapkan dapat memperkaya literatur dengan memberikan bukti empiris pengaruh faktor-faktor dalam fraud diamond theory yaitu tekanan keuangan, tekanan kebiasaan, tekanan hubungan pekerjaan, tekanan faktor lainnya, rasionalisasi umum, paksaan dan penipuan pada salah kelola aset tetap.

\section{Keterbatasan dan Saran}

Penelitian ini terdapat kekurangan dan keterbatasan yang diharapkan menjadi masukan dan dapat diakukan oleh peneliti berikutnya, yaitu: pembagian kuesioner dilakukan pada saat kondisi work load sehingga kondisi tekanan pekerjaan yang besar yang dialami responden menjadi penyebab tidak optimalnya jawaban responden. Hal ini dapat dilihat dari distribusi sebanyak 296 kuesioner yang disebar pada 46 OPD, terdapat 41 responden atau $13,85 \%$ responden yang tidak merespon/ memberikan jawaban pada kuesioner.

\section{DAFTAR PUSTAKA}

Abdullahi, R. and Mansor, N. (2015) 'Fraud Triangle and Fraud Diamond Theory, Understanding the Convergent and Divergent For Future Research', International Journal of Academic Research in Accounting, Finance and Management Science, 5(4), pp. 38-45.

ACFE (2016) Report to Nation on Occupational Fraud and Abuse ACFE Association of Certified Fraud Examiner.

Albrecht, C., Kranacher, M.-J. and Albrecht., S. (2008) Asset Misappropriation Research White Paper for the Institute for Fraud Prevention.

Albrecht, W. S. et al. (2011) Fraud Examination. Boston, United States: Cengage Learning. 
BPK RI 2016, Ikhtisar Hasil Pemeriksaan Sementara (IHPS) II Tahun 2016, edited by BPK RI, Indonesia

Cressey, D. R. (1950) 'Other People's Money; A Study of The Social Psychology of Embezzlement', Book Review, 2(2), p. 290.

Devianasari, D. (2016) Analisa Faktor - faktor yang Mempengaruhi Terjadinya Fraud pada Sektor Pemerintahan Kota Bandarlampung: Persepsi Pegawai Pemerintahan. Universitas Lampung, Lampung.

Ekadah, J. (2016) 'Asset Misappropriation/Fraud', in ICPAK 2016 Annual Forensic Audi Conference.

Ghozali, I. (2013) Aplikasi Analisis Multivariate dengan Program SPSS. Semarang, Indonesia: Badan Penerbit Universitas Diponegoro.

Heider, F. (1958) The Psychology of Interpersonal Relations. New York: John Wiley and Sons, Inc.

I., M., M, S. and Nurkholis (2017) 'Pengaruh Dimensi Fraud Diamond Terhadap Perilaku Kecurangan Akademik (Studi Empiris pada Mahasiswa Magister Akuntansi Universitas Brawijaya)', Jurnal Ekonomi, 4(2 Juni 2017), pp. 121-133.

Irphani, A. (2017) Pengaruh Tekanan, Kefektifan Sistem Pengendalian Internal, Perilaku Tidak Etis dan Jabatan dalam Pengelolaan Keuangan Terhadap Fraud. Universitas Lampung, lampung.
Lokanan, E. M. (2015) 'Challenges to The Fraud Triangle: Questions on its Usefulness', Journal of Accounting Forum, 39(2015), pp. 201224.

Mackevičius, J. and Giriūnas, L. (2013) 'Transformational Research of The Fraud Triangle', Ekonomika, 92(4), pp. 150-163.

Manurung, D. T. H. and Hardika, H. L. (2015) 'Analysis of Factors That Influences Financial Statement Fraud in The Perpective Fraud Diamond: Empirical Study on Banking Companies Listed on The Indonesia Stock Exchange year 20102 to 2014', in International Conference on Accounting Studies (ICAS) $2015 \quad$ 17-20 August 2015, Johor Bahru, Johor, Malaysia.

Marliani, M. and Jogi, Y. (2015) 'Persepsi Pengaruh Fraud Triangle Terhadap Pencurian Kas', Business Accounting Review, 3(2), pp. 21-30.

Nia, E. H. and Said, J. (2015) 'Assessing Fraud Risk Factors of Assets Misappropriation: Evidences from Iranian Banks', Procedia Economics and Finance Journal, 31(2015), pp. 919-924.

Nursani, R. and Irianto, G. (2014) Perilaku Kecurangan Akademik Mahasiswa:

Dimensi Fraud Diamond. Universitas Brawijaya, Malang.

Owens, C. (2010) Misappropriation of Assets : Ask The Author.

Pamungkas, D. D. (2015) Pengaruh 
Faktor - Faktor Dalam

Dimensi Fraud Triangle

Terhadap Perilaku

Kecurangan Akademik Siswa

Kelas XI Akuntansi SMK

Negeri 1 Tempet Tahun

2014/2015, Fakultas

Ekonomi UNY, tahun

2014/2015. Universitas

Negeri Yogyakarta,

Yogyakarta.

Purnamasari, P. and Okotroza, M. (2015) 'Influence of Employee Fraud on Asset Misappropriation Analysed by Fraud Diamond Dimension', in International Conference on Accounting Studies (ICAS) 2015, Aug 1720, 2015.

Purwanto, E. et al. (2016) 'Kajian Konsep Diamond Fraud Theory Dalam Menunjang Efektivitas Pengadaan Barang/Jasa di Pemerintah Kota Bogor', Jurnal Manajemen Indonesia, 17(3), pp. 149-162.

Rae, K. and Subramanian, N. (2008) 'Quality of Internal Control Procedures : Antecendents and Moderating Effect on Organisational Justice and Employee Fraud', Managerial Auditing Journal, 23(2), pp. 104-124.

Ruankaew, T. (2016) 'Beyond The Fraud Diamond', International Journal of Business Management and Economic Research (IJBMER), 7(1), pp. 474-476.
Shelton, M. A. (2014) Analysis of Cappability Attributed to The Fraud Diamond. East Tennesee State University, England.

Skousen, C., Wright, J. C. and Smith, K. R. (2009) 'Detecting and Predicting Financial Statement Fraud: The Effectiveness of Fraud Triangle and SAS No.99', Advances in Financial Economics, 13(2009), pp. 5381.

Wibowo, A. (2017) Implementasi Triangle Fraud dalam Mendeteksi Penyalahgunaan Aset. Universitas Diponegoro, Semarang.

Widarti (2015) 'Pengaruh Fraud Triangle Terhadap Deteksi Kecurangan Laporan Keuangan Pada Perusahaan Manufaktur Yang Terdaftar Di Bursa Efek Indonesia', Jurnal Manajemen dan Bisnis Sriwijaya, 13(2), pp. 229244.

Wolfe, D. T. and Hermanson, R. D. (2004) 'The Fraud Diamond: Considering the Four Element of Fraud', The CPA Journal, 74(12), pp. 38-42.

Zahara, A. (2017) Pengaruh Tekanan, Kesempatan dan Rasionalisasi terhadap Tindakan Kecurangan (Fraud)' Survey pada Narapidana Tipikor di Lembaga Pemasyarakatan Kelas IIa Kota Pekanbaru. Universitas Negeri Padang. 